\title{
Involvement of Coenzyme A Esters in the Metabolism of Benzoate and Cyclohexanecarboxylate by Rhodopseudomonas palustris
}

\author{
By GEORGINA N. HUTBER* AND DOUGLAS W. RIBBONS \\ Department of Biochemistry and Soil Science, University College of North Wales, Bangor, \\ Gwynedd LL57 2UW, U.K.
}

(Received 20 December 1982; revised 23 March 1983)

\begin{abstract}
Rhodopseudomonas palustris was grown on benzoate, cyclohexanecarboxylate or succinate under anaerobic or aerobic conditions. Studies of oxygen uptake by intact bacteria indicated that cyclohexanecarboxylate was metabolized aerobically by a $\beta$-oxidation sequence and that cultures grown anaerobically on benzoate also possessed this capacity. Bacteria grown on succinate were able to oxidize octanoate but not alicyclic acids. The enzymes necessary for the $\beta$ oxidation of cyclohexanecarboxylate appeared to be constitutive in both anaerobic and aerobic bacteria, the only exception being an acyl-CoA synthetase which used benzoate and some alicyclic acids as substrates. This acyl-CoA synthetase differed from the constitutive short-chain fatty acyl-CoA synthetase in that it was induced by anaerobic growth on benzoate or by aerobic growth on cyclohexanecarboxylate.
\end{abstract}

\section{INTRODUCTION}

The pathways of aerobic metabolism of aromatic compounds are now well documented (Dagley, 1975) and involve molecular oxygen in ring fission reactions. Any organism which can utilize aromatic compounds under anaerobic conditions must therefore employ rather different tactics. A number of such organisms have been described, growing on various aromatic substrates, including Pseudomonas sp. (Taylor et al., 1970; Balba \& Evans, 1980), Moraxella sp. (Williams \& Evans, 1975), Bacillus sp. (Aftring \& Taylor, 1981), methanogenic consortia (Balba

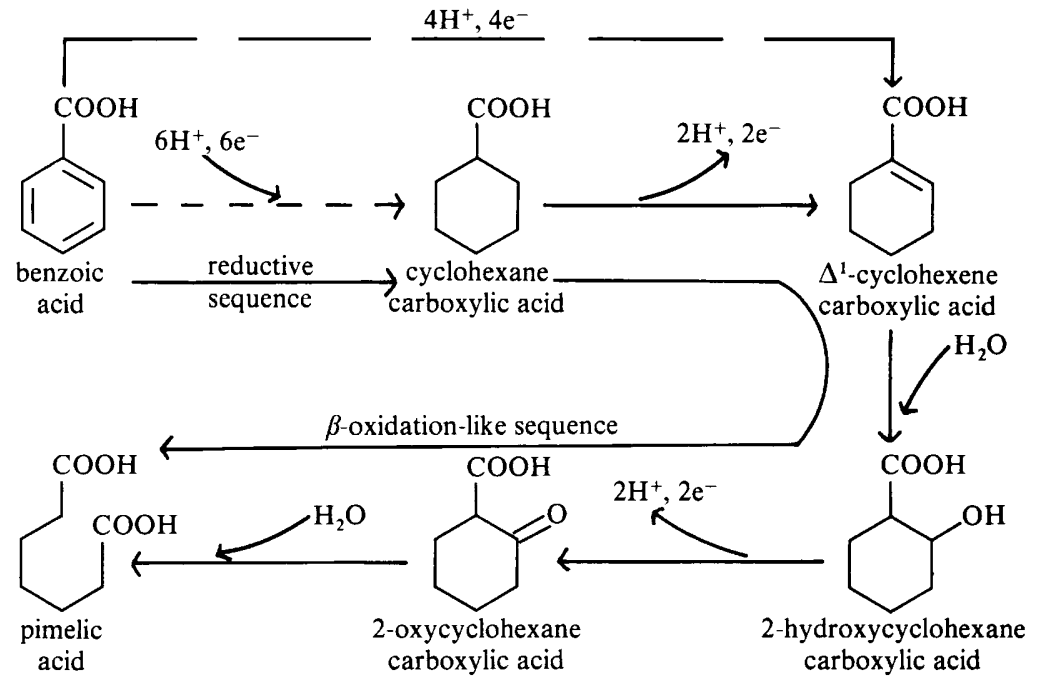

Fig. 1. Proposed pathway of anaerobic benzoate metabolism (after Dutton \& Evans, 1969). 
\& Evans, 1977) and several species of Rhodospirillaceae (Dutton \& Evans, 1976). Although a scheme involving hydroxylation of the aromatic nucleus was suggested (Taylor et al., 1970), the weight of experimental evidence undoubtedly supports a reductive mechanism to give alicyclic products (Dutton \& Evans, 1968, 1969; Guyer \& Hegeman, 1969; Williams \& Evans, 1975). In Rhodopseudomonas palustris these are then metabolized by a sequence of reactions resembling $\beta$ oxidation (Fig. 1). Some evidence was obtained for the involvement of benzoyl-CoA (Whittle et al., 1976), and though this was insubstantial it formed the starting point for the present study of the metabolism of benzoate and cyclohexanecarboxylate by $R$. palustris.

\section{METHODS}

Organism. The purple non-sulphur bacterium Rhodopseudomonas palustris (Hegeman strain) was obtained in this department from Dr P. A. Williams. Master stock cultures were maintained in nutrient agar stabs and working stocks in $50 \mathrm{ml}$ nutrient broth in $100 \mathrm{ml}$ Erlenmeyer flasks, which were kept without shaking at room temperature under low light.

Growth of bacteria. Liquid cultures of $R$. palustris were grown in medium containing $\left(1^{-1}\right): \mathrm{KH}_{2} \mathrm{PO}_{4}, 6 \cdot 8 \mathrm{~g}$; $\left(\mathrm{NH}_{4}\right)_{2} \mathrm{SO}_{4}, 1.2 \mathrm{~g}$; 4-aminobenzoate, $0.1 \mathrm{mg}$; trace element solution (Bauchop \& Elsden, 1960), $10 \mathrm{ml}$. Carbon sources were supplied at $0 \cdot 1 \%(\mathrm{w} / \mathrm{v})$ in the case of cyclohexanecarboxylate, $\Delta^{1}$-cyclohexenecarboxylate and benzoate, or at $0 \cdot 3 \%(\mathrm{w} / \mathrm{v})$ for succinate and acetate (all as their sodium salts) and the $\mathrm{pH}$ was adjusted to 7.2. The sequence of transfers to grow cell cultures was as follows. Nutrient broth $(10 \mathrm{ml})$ in a McCartney bottle was inoculated with $1 \mathrm{ml}$ nutrient broth stock culture and incubated at $30^{\circ} \mathrm{C}$ for $2 \mathrm{~d}$. For aerobic cultures, $5 \mathrm{ml}$ of this was used to inoculate $50 \mathrm{ml}$ mineral salts medium in a $100 \mathrm{ml}$ Erlenmeyer flask; cultures were grown with shaking at $30^{\circ} \mathrm{C}$ for $4 \mathrm{~d}$ before being used as inoculum $(25 \mathrm{ml})$ for $250 \mathrm{ml}$ medium in a $500 \mathrm{ml}$ flask. For anaerobic cultures, $2.5 \mathrm{ml}$ nutrient broth starter culture was used to inoculate mineral salts medium in a $25 \mathrm{ml}$ McCartney bottle, which was then completely filled with sterile medium. This was incubated in an illuminated water bath (eight $40 \mathrm{~W}$ tungsten lamps, irradiance $8 \mathrm{~mW} \mathrm{~cm}^{-2}$ at the inside surface of the bath) for 4 to $5 \mathrm{~d}$ and the entire culture was used to inoculate medium in a $250 \mathrm{ml}$ medical flat. This was also filled with medium and incubated in the water bath for 5 to $6 \mathrm{~d}$.

Cultures were harvested at $4{ }^{\circ} \mathrm{C}$ by centrifugation at $3500 \mathrm{~g}$ for $10 \mathrm{~min}$. The cell paste was washed with $42 \mathrm{mM}$ sodium/potassium phosphate buffer, $\mathrm{pH} 7 \cdot 1$ (made by dissolving $4 \mathrm{~g}$ of $\mathrm{Na}_{2} \mathrm{HPO}_{4}$ and $2 \mathrm{~g}$ of $\mathrm{KH}_{2} \mathrm{PO}_{4}$ in 1 litre distilled water), followed by further centrifugation at $10000 \mathrm{~g}$ for $10 \mathrm{~min}$; the pellet was finally resuspended in 2 vol. of the appropriate buffer.

Cell-free extracts. Extracts were prepared from suspensions of cells in $100 \mathrm{mM}$-Tris/ $\mathbf{H C l}$ buffer, $\mathrm{pH} 8 \cdot 0$ (for acylCoA synthetase assays) or $42 \mathrm{~mm}$-sodium/potassium phosphate buffer, $\mathrm{pH} 7 \cdot 1$ (all other assays) by a single passage through a chilled French pressure cell (American Instrument Co., Silver Spring, Md., U.S.A.) with a pressure difference at the orifice of $140 \mathrm{MPa}\left(20000 \mathrm{lbf} \mathrm{in}^{-2}\right)$. The supernatant was obtained by centrifugation at $20000 \mathrm{~g}$ for $10 \mathrm{~min}$ at $4{ }^{\circ} \mathrm{C}$. Protein content was measured by the modified biuret method and cell extracts usually contained 20 to $25 \mathrm{mg}$ protein $\mathrm{ml}^{-1}$.

Manometry. Manometric studies were conducted with constant-volume manometers (Braun, Melsungen, F.R.G.) at $30^{\circ} \mathrm{C}$. Oxygen consumption was followed in the presence of $\mathrm{KOH}$ in the centre well. $\mathrm{CO}_{2}$ consumption under anaerobic conditions was measured after equilibrating with an atmosphere of $\mathrm{N}_{2} / \mathrm{CO}_{2}(95: 5, \mathrm{v} / \mathrm{v})$ before addition of substrates. The flasks were illuminated with fourteen $40 \mathrm{~W}$ tungsten bulbs (irradiance $23 \mathrm{~mW} \mathrm{~cm}^{-2}$, at the base of the flasks). In both cases $42 \mathrm{~mm}$-phosphate buffer, $\mathrm{pH} 7 \cdot 1$, was used.

Enzyme assays. Acyl-CoA synthetase (EC6.2.1.-) was assayed by the method of Overath et al. (1969) as modified by Blakley (1978). Acyl-CoA dehydrogenase (EC1.3.99.3) was assayed as described by O'Brien \& Frerman (1977) and enoyl-CoA hydratase (EC 4.2.1.17) and $\beta$-hydroxyacyl-CoA dehydrogenase (EC 1.1.1.35) as described by Weeks et al. (1969). $\beta$-Oxoacyl-CoA thiolase (EC2.3.1.9) was assayed as described by Clinkenbeard et al. (1973). Acyl-CoA dehydrogenase was also assayed polarographically, omitting the tetrazolium dye, using a Clark oxygen electrode (Yellow Springs Instrument Co., Yellow Springs, Ohio, U.S.A.).

Chemicals. 2-Oxocyclohexanecarboxylic acid was prepared from its ethyl ester by a method similar to that of Krueger (1952). trans-2-Hydroxycyclohexanecarboxylic acid was also prepared from the ethyl ester of the 2-oxo acid by the method of Dieckmann (1894). Both were gifts from Professor W.C. Evans. $N$-Hydroxysuccinimide esters of octanoic and benzoic acids and of the cyclohexanecarboxylic acids were prepared by the method of Lapidot et al. (1967) and recrystallized from warm ethyl acetate/petroleum $\left(40-60^{\circ} \mathrm{C}\right)$. CoA esters were then prepared from the $N$-hydroxysuccinimide esters as described by Ougham \& Trudgill (1982). Acetoacetyl-CoA, crotonyl-CoA, benzoyl-CoA, phenazine methosulphate, ATP, NAD, NADH, CoASH, dithiothreitol, 3-(4,5dimethylthiazoyl-2)-2,5-diphenyltetrazolium bromide, dicyclohexylcarbodiimide, $N$-hydroxysuccinimide and $\beta$ hydroxyacyl-CoA dehydrogenase were supplied by Sigma. Cyclohexanecarboxylic acid was from Aldrich. $\Delta^{1}-$ Cyclohexenecarboxylic acid was from Pfaltz and Bauer (via Phase-Separations Ltd, Queensferry, Clwyd, U.K.) 
and ethyl-2-oxocyclohexanecarboxylic acid from Fluka (via Fluorochem Ltd, Glossop, Derbyshire, U.K.). Cyclohexaneacetic acid, cyclohexanepropionic acid, cyclopentanecarboxylic acid and cyclopentaneacetic acid were gifts from Dr P. W. Trudgill.

\section{RESULTS}

\section{Growth of $R$. palustris}

In general agreement with previous work (Dutton \& Evans, 1969) $R$. palustris grew anaerobically (photosynthetically) on benzoate and more slowly on 3-hydroxybenzoate and 4-hydroxybenzoate. It also grew anaerobically on cyclohexanecarboxylate and $\Delta^{1}$-cyclohexenecarboxylate, though rather slowly and with lower growth yields. Rhodopseudomonas palustris grew aerobically (in the dark) on cyclohexanecarboxylate and $\Delta^{1}$-cyclohexenecarboxylate but not on benzoate. Acetate and succinate supported growth both anaerobically and aerobically.

\section{Respiratory studies with $R$. palustris grown anaerobically and aerobically}

Whole cells of $R$. palustris grown anaerobically (photosynthetically) on benzoate or succinate oxidized octanoate immediately under aerobic incubation conditions (Fig. 2). Benzoate-grown cells immediately oxidized cyclohexanecarboxylate (initial rate of $\mathrm{O}_{2}$ uptake, $3 \cdot 1 \mu \mathrm{mol} \mathrm{h}^{-1}$ ) and $\Delta^{1}$-cyclohexenecarboxylate $\left(2.9 \mu \mathrm{mol} \mathrm{h}^{-1}\right)$ at a slower rate than octanoate $\left(5.3 \mu \mathrm{mol} \mathrm{h}^{-1}\right)$ but faster than 2-hydroxycyclohexanecarboxylate $\left(2 \cdot 0 \mu \mathrm{mol} \mathrm{h}^{-1}\right)$ and 2-oxocyclohexanecarboxylate $\left(1 \cdot 2 \mu \mathrm{mol} \mathrm{h}^{-1}\right)$. Cells grown anaerobically on succinate did not oxidize any of these alicyclic acids at significant initial rates though there was perhaps some indication of induced oxidation after incubation for $40 \mathrm{~min}$. The pattern of oxidation of substrates by cells grown aerobically on succinate was similar to that with anaerobic cultures. Cells grown aerobically on cyclohexanecarboxylate or $\Delta^{1}$-cyclohexenecarboxylate oxidized the growth substrates 2-hydroxycyclohexanecarboxylate and 2-oxocyclohexanecarboxylate as well as octanoate.

Cultures grown on benzoate (anaerobically) or on cyclohexanecarboxylate (aerobically) oxidized cyclopentanecarboxylate at rates similar to cyclohexanecarboxylate (Table 1). Cyclohexanepropionate was oxidized by these cell suspensions and also by succinate-grown cells. It was further found that cyclopentaneacetate and cyclohexaneacetate were oxidized at much
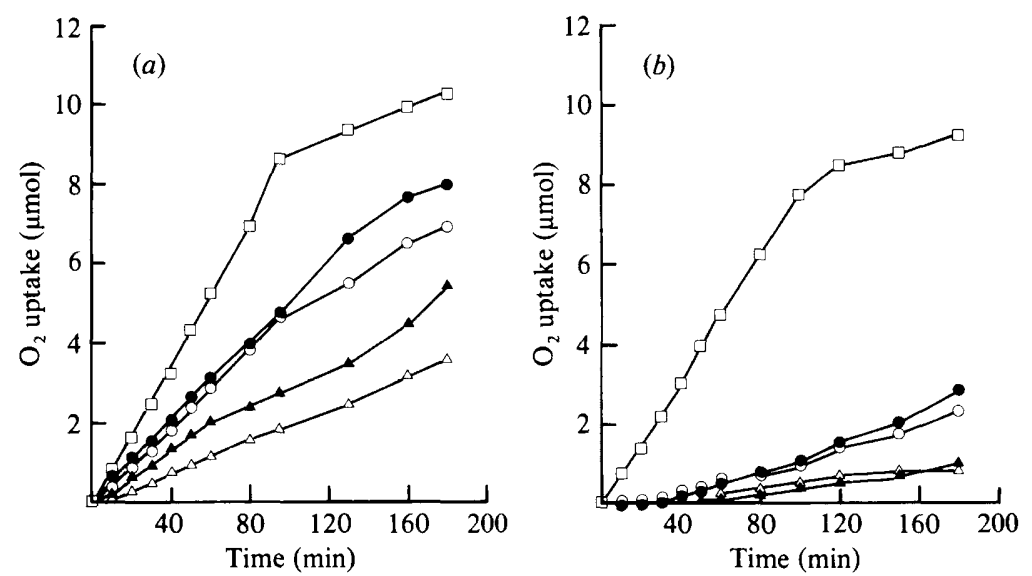

Fig. 2. Respiratory activities of $R$. palustris grown anaerobically on $(a)$ benzoate or $(b)$ succinate. Each Warburg flask contained, in a volume of $1.9 \mathrm{ml}$ : sodium/potassium phosphate buffer $(\mathrm{pH} 7 \cdot 1), 70 \mu \mathrm{mol}$; cell suspension, $15 \mathrm{mg}$ (dry wt); substrate, $3 \mu \mathrm{mol}$. The centre well contained $0.1 \mathrm{ml} 20 \%(\mathrm{w} / \mathrm{v}) \mathrm{KOH}$. Reactions at $30^{\circ} \mathrm{C}$ were initiated by tipping substrates from the side arms : octanoate ( $\square$ ); cyclohexanecarboxylate $(\mathbf{O}) ; \Delta^{1}$-cyclohexenecarboxylate $(O) ; 2$-hydroxycyclohexanecarboxylate (A); 2-oxocyclohexanecarboxylate $\left(\triangle\right.$ ). Endogenous respiration was low (approximately $1 \mu \mathrm{mol} \mathrm{h}^{-1}$ ) and was subtracted. The atmosphere was air. 

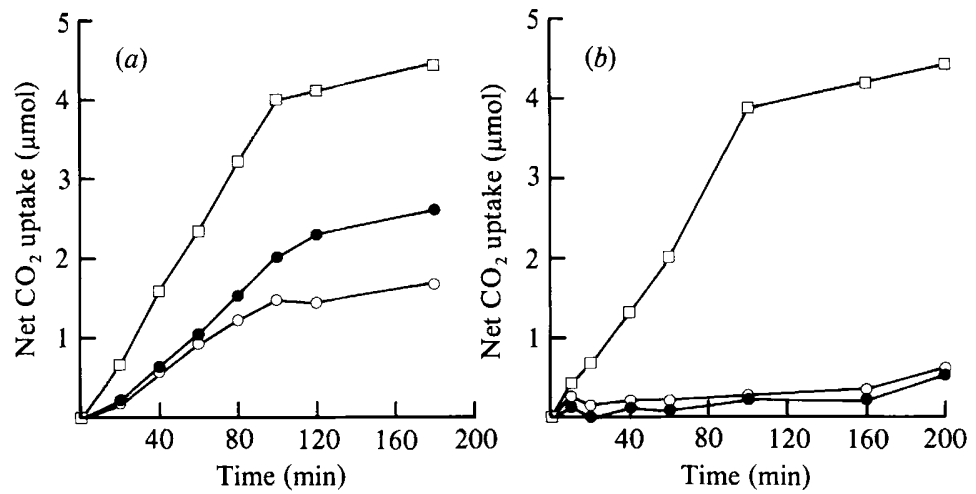

Fig. 3. Utilization of substrates by $R$. palustris grown anaerobically on $(a)$ benzoate or $(b)$ succinate. Each Warburg flask contained, in a volume of $2 \mathrm{ml}$ : sodium/potassium phosphate buffer $(\mathrm{pH} 7 \cdot 1)$, $70 \mu \mathrm{mol}$; cell suspension, $8 \mathrm{mg}$ (dry wt); substrate, $3 \mu \mathrm{mol}$. Reactions at $30^{\circ} \mathrm{C}$ were initiated by tipping substrates from the side arms: octanoate $(\square)$; cyclohexanecarboxylate $(\bigcirc) ; \Delta^{1}$-cyclohexenecarboxylate (O). The flasks were illuminated throughout the experiment. The atmosphere was $\mathrm{N}_{2} / \mathrm{CO}_{2}(95: 5, \mathrm{v} / \mathrm{v})$. Negligible rates of endogenous $\mathrm{CO}_{2}$ evolution were observed $\left(<0.1 \mu \mathrm{mol} \mathrm{h}^{-1}\right)$.

Table 1. Substrate oxidation by whole cells of R. palustris grown aerobically or anaerobically on different carbon sources

Conditions were identical to those described in Fig. 2. Values are initial rates of $\mathrm{O}_{2}$ uptake with $3 \mu \mathrm{mol}$ of substrate.

\begin{tabular}{|c|c|c|c|c|}
\hline & & ial rate of $C$ & ptake $(\mu \mathrm{mol} \mathrm{h}$ & \\
\hline & Anaerol & wth on: & Aerobic & vth on: \\
\hline Substrate & Benzoate & Succinate & $\begin{array}{l}\text { Cyclohexane } \\
\text { carboxylate }\end{array}$ & Succinate \\
\hline te & $5 \cdot 3$ & $4 \cdot 7$ & $10 \cdot 3$ & $8 \cdot 7$ \\
\hline anecarboxylate & $3 \cdot 1$ & 0.5 & $9 \cdot 2$ & $1 \cdot 3$ \\
\hline exaneacetate & 0.7 & 0.8 & $0 \cdot 1$ & 0.9 \\
\hline exanepropionate & $5 \cdot 1$ & $2 \cdot 6$ & $8 \cdot 4$ & $4 \cdot 0$ \\
\hline entanecarboxylate & $2 \cdot 7$ & $0 \cdot 9$ & $5 \cdot 6$ & $1 \cdot 2$ \\
\hline entaneacetate & 0.8 & 0.6 & $0 \cdot 2$ & 0.9 \\
\hline & 0.0 & $0 \cdot 0$ & 0.0 & $0 \cdot 0$ \\
\hline
\end{tabular}

slower rates by suspensions of cells which had been grown under any conditions. These two acids are not substrates for $\beta$-oxidation. No oxygen uptake by any of the cell suspensions was observed with benzoate. Cells grown on acetate exhibited a very similar pattern of oxidation of substrates to cells grown on succinate (results not shown).

Under an atmosphere of $\mathrm{N}_{2} / \mathrm{CO}_{2}$, net $\mathrm{CO}_{2}$ uptake was observed with octanoate as substrate, by cells grown anaerobically on benzoate or succinate (Fig. 3). Gas uptake was recorded with cyclohexanecarboxylate and $\Delta^{1}$-cyclohexenecarboxylate for cells grown on benzoate but not on succinate. $\mathrm{Net} \mathrm{CO}_{2}$ uptake was not observed with benzoate for either cell suspension. In the absence of substrate, no net change in gas pressure was recorded, as was also the case in the absence of light.

\section{Assay of acyl-CoA synthetase activity}

Acyl-CoA synthetase activity in crude extracts was assayed with a number of substrates. The activity varied up to twofold from extract to extract, though the relative activities with different 
Table 2. Acyl-CoA synthetase activity of $R$. palustris grown under various conditions

Acyl-CoA synthetase activities were assayed at $\mathrm{pH} 8.0$ as described in Methods. The specific activities of octanoyl-CoA synthetase were 4 and $6.4 \mathrm{nmol} \mathrm{CoA}$ ester formed $\mathrm{min}^{-1}$ (mg protein $)^{-1}$ for extracts of anaerobic and aerobic cultures, respectively. Values marked with an asterisk were determined in a separate experiment.

Assay substrate

Benzoate

Cyclohexanecarboxylate

$\Delta^{1}$-Cyclohexenecarboxylate

2-Hydroxycyclohexanecarboxylate

2-Oxocyclohexanecarboxylate

Cyclopentanecarboxylate

Cyclohexanepropionate
Activity (\%) relative to octanoyl-CoA synthetase

\begin{tabular}{|c|c|c|c|}
\hline \multicolumn{2}{|c|}{ Anaerobic growth on: } & \multicolumn{2}{|c|}{ Aerobic growth on: } \\
\hline Benzoate & Succinate & $\begin{array}{l}\text { Cyclohexane } \\
\text { carboxylate }\end{array}$ & Succinate \\
\hline $48 \cdot 6$ & $9 \cdot 9$ & $49 \cdot 3$ & $13 \cdot 7$ \\
\hline $49 \cdot 5$ & $36 \cdot 6$ & $55 \cdot 4$ & $38 \cdot 8$ \\
\hline $9 \cdot 6$ & $4 \cdot 8$ & $7 \cdot 3$ & $6 \cdot 1$ \\
\hline $6 \cdot 7$ & 1.8 & $6 \cdot 7$ & $0 \cdot 2$ \\
\hline $17 \cdot 9$ & $17 \cdot 6$ & $6 \cdot 2$ & 11.6 \\
\hline $75 \cdot 8^{*}$ & $38.8^{*}$ & $72 \cdot 4$ & $52 \cdot 6$ \\
\hline $61 \cdot 3$ & $65 \cdot 2$ & $69 \cdot 2$ & $73 \cdot 3$ \\
\hline
\end{tabular}

substrates were reasonably constant. The results of two typical experiments, one with an extract of anaerobically grown cells and the other with aerobically grown cells are shown in Table 2 . All the extracts contained octanoyl-CoA synthetase activity, within the range 4 to $8 \mathrm{nmol} \mathrm{CoA}$ ester formed $\min ^{-1}$ (mg protein) $)^{-1}$. Extracts of cells grown on succinate also contained appreciable activity with cyclohexanecarboxylate, cyclopentanecarboxylate and cyclohexanepropionate, though activity towards other substrates was low (Table 2). In extracts of cells grown anaerobically on benzoate, there was a large increase in benzoyl-CoA synthetase activity and a concomitant increase with cyclohexanecarboxylate and cyclopentanecarboxylate. There was no increase in the already high level of activity towards cyclohexanepropionate and little or no change in synthetase activity with $\Delta^{1}$-cyclohexenecarboxylate, 2-hydroxycyclohexanecarboxylate or 2-oxocyclohexanecarboxylate.

Aerobic growth on cyclohexanecarboxylate produced a marked increase in benzoyl-CoA synthetase activity even though $R$. palustris does not grow aerobically on benzoate.

\section{Assay of enzymes of $\beta$-oxidation}

If cyclohexanecarboxyl-CoA is further metabolized by $\beta$-oxidation, the presence of the enzymes acyl-CoA dehydrogenase, enoyl-CoA hydratase, $\beta$-hydroxyacyl-CoA dehydrogenase and thiolase is necessary. These were assayed in cell extracts with both short-chain aliphatic substrates and the putative CoA ester intermediates of benzoate metabolism. There were no significant differences in activity with short-chain substrates between extracts of cells grown on benzoate or cyclohexanecarboxylate and of cells grown on succinate (Table 3). The results for acyl-CoA dehydrogenase were confirmed by linking the reduction of phenazine methosulphate directly to oxygen in polarographic assays. It is evident that the CoA esters of the alicyclic acids are also active as substrates for enzymes in these extracts. The specific activities determined with $\mathrm{CoA}$ esters synthesized in the laboratory are rather low because insufficient substrate was available for the development of optimal assay conditions and assays were performed with less than saturating concentrations of substrate.

Thiolase was assayed with acetoacetyl-CoA as substrate by following the decrease in absorbance at $300 \mathrm{~nm}$. No change in any part of the spectrum of 2-oxocyclohexanecarboxylCoA was observed on addition of cell extract to the assay mixture. The negligible activity recorded with this substrate may be due to lack of enzyme activity or to failure to detect activity. The cyclic CoA ester might possibly be cleaved by a CoA ester transferase rather than a thiolase, though this has not yet been tested. 
Table 3. Activities of enzymes involved in $\beta$-oxidation in $R$. palustris

Enzymes were assayed as described in Methods. Activity is expressed as nmol product formed (substrate utilized for thiolase) $\min ^{-1}$ (mg protein) ${ }^{-1}$.

\begin{tabular}{|c|c|c|c|c|c|}
\hline \multirow[b]{3}{*}{ Enzyme } & \multirow[b]{3}{*}{ Substrate } & \multicolumn{4}{|c|}{ Activity in extracts of cells grown } \\
\hline & & \multicolumn{2}{|c|}{ Anaerobically on: } & \multicolumn{2}{|c|}{ Aerobically on: } \\
\hline & & Benzoate & Succinate & $\begin{array}{l}\text { Cyclohexane } \\
\text { carboxylate }\end{array}$ & Succinate \\
\hline \multirow{2}{*}{$\begin{array}{l}\text { Acyl-CoA } \\
\text { dehydrogenase }\end{array}$} & Octanoyl-CoA & $3 \cdot 7$ & $3 \cdot 1$ & 3.9 & 3.9 \\
\hline & $\begin{array}{l}\text { Cyclohexane } \\
\text { carboxyl-CoA }\end{array}$ & 3.9 & $3 \cdot 4$ & $6 \cdot 4$ & $6 \cdot 1$ \\
\hline \multirow{2}{*}{$\begin{array}{c}\beta \text {-Hydroxyacyl-CoA } \\
\text { dehydrogenase }\end{array}$} & Acetoacetyl-CoA & 324.0 & $204 \cdot 0$ & $346 \cdot 0$ & $326 \cdot 0$ \\
\hline & $\begin{array}{l}\text { 2-Oxocyclohexane } \\
\text { carboxyl-CoA }\end{array}$ & $7 \cdot 6$ & $6 \cdot 3$ & $10 \cdot 2$ & $9 \cdot 7$ \\
\hline \multirow{2}{*}{$\begin{array}{l}\text { Enoyl-CoA } \\
\text { hydratase }\end{array}$} & Crotonyl-CoA & $15 \cdot 3$ & $14 \cdot 6$ & $10 \cdot 3$ & $10 \cdot 8$ \\
\hline & $\begin{array}{l}\Delta^{1} \text {-Cyclohexene } \\
\text { carboxyl-CoA }\end{array}$ & $3 \cdot 2$ & $3 \cdot 7$ & $2 \cdot 9$ & $3 \cdot 0$ \\
\hline Thiolase & Acetoacetyl-CoA & $124 \cdot 0$ & $177 \cdot 0$ & $571 \cdot 0$ & $717 \cdot 0$ \\
\hline
\end{tabular}

\section{Induction experiments}

Assay of acyl-CoA synthetase in extracts showed that growth in the presence of benzoate or cyclohexanecarboxylate produced an increase in activity towards some cyclic substrates. The role of these two compounds as inducers was confirmed by incubation experiments in which cells were grown on succinate either aerobically or anaerobically, harvested, washed under aseptic conditions and then incubated aerobically with benzoate or anaerobically with cyclohexanecarboxylate. These are both effectively non-growing conditions, since anaerobic growth on cyclohexanecarboxylate is very slow. Control incubations contained no carbon source. After $2 \mathrm{~d}$, enzyme activity in extracts was measured. Incubation of cells with benzoate under aerobic conditions produced an increase in benzoyl-CoA synthetase activity to about $18 \%$ of the octanoyl-CoA synthetase activity and also an increase in activity towards cyclohexanecarboxylate. Similar results were obtained on incubation of cells anaerobically with cyclohexanecarboxylate. Little, if any, effect was observed after shorter incubation times.

\section{DISCUSSION}

The whole-cell oxidation studies showed the presence in $R$. palustris of a constitutive $\beta$ oxidation system for short-chain fatty acids which was also capable of limited utilization of cyclohexanepropionate, presumably because of its linear side-chain. Growth on cyclohexanecarboxylate (aerobic) or benzoate (anaerobic) induced the capacity for oxidation of cyclohexanecarboxylate and its derivatives. At the same time, oxidation of cyclopentanecarboxylate was induced, though neither cyclopentaneacetate nor cyclohexaneacetate was oxidized to any great extent. Since neither of these is a substrate for a complete cycle of $\beta$-oxidation, this is strong circumstantial evidence that cyclohexanecarboxylate and its derivatives are metabolized by $\beta$ oxidation. This metabolic route has been described for many aerobic organisms (Rho \& Evans, 1975; Blakley, 1978; Taylor \& Trudgill, 1978).

Under anaerobic, photosynthetic conditions, $\mathrm{CO}_{2}$ production by catabolism and $\mathrm{CO}_{2}$ fixation by the Calvin cycle occur simultaneously, and in the presence of an organic substrate the net result depends upon whether this substrate is more or less reduced than cell material (Ormerod, 1956). This makes detailed interpretation of the anaerobic manometric experiments rather more difficult, though the differences were significant. Only cells grown on benzoate in 
the light exhibited substrate-stimulated net uptake of $\mathrm{CO}_{2}$ when incubated in the light with cyclohexanecarboxylate and $\Delta^{1}$-cyclohexenecarboxylate. On the other hand, net $\mathrm{CO}_{2}$ uptake was observed with octanoate as substrate by cell suspensions grown on either benzoate or succinate. This confirms that there is a constitutive capacity to metabolize octanoate anaerobically and that the anaerobic metabolism of cyclohexanecarboxylate is inducible.

The enzyme assays provided results which were consistent with those of the manometric experiments. All the enzymes necessary for the $\beta$-oxidation of short-chain fatty acids were shown to be constitutive. In addition, alicyclic CoA esters could act as substrates for enzymes in the extracts which were present at similar levels under all growth conditions. It is probable that these enzymes are the same ones as for constitutive $\beta$-oxidation, since growth on benzoate or cyclohexanecarboxylate rather than succinate produced no change in the ratios of the activities measured. Growth on either benzoate or cyclohexanecarboxylate did, however, induce an acylCoA synthetase which was active with benzoate and with some alicyclic substrates. Since succinate-grown cells have constitutive $\beta$-oxidation enzymes and reasonable acyl-CoA synthetase activity towards cyclopentanecarboxylate and cyclohexanecarboxylate, yet do not oxidize these in whole-cell studies, presumably the induction of a transport system is necessary for the utilization of these substrates. Cyclohexanepropionate may be sufficiently similar to straight-chain fatty acids for uptake to occur via a common system.

The appearance of a benzoyl-CoA synthetase in response to benzoate is the first positive evidence to indicate that the substrate for reduction of the aromatic nucleus is benzoyl-CoA. Previous work (Whittle et al., 1976) showed merely the disappearance of a small amount of benzoate in the presence of CoASH, ATP and cell extract. The first product of the reduction has not yet been identified (Dutton \& Evans, 1969), but it seems reasonable that this leads to cyclohexanecarboxyl-CoA, which can easily be incorporated into the $\beta$-oxidation sequence. Otherwise partial reduction of the benzene ring with retention of a specific double bond must be postulated.

It is clear that neither the formation of benzoyl-CoA nor the $\beta$-oxidation of cyclohexanecarboxyl-CoA is necessarily an anaerobic process. Aerobic growth on cyclohexanecarboxylate induces the ability to form benzoyl-CoA, while anaerobic growth on benzoate induces the capacity to oxidize cyclohexanecarboxylate aerobically. The process which is unique to the anaerobic photometabolism of benzoate is the actual reduction of the aromatic nucleus and this is currently under study.

Note added in proof. The product of the acyl-CoA synthetase assay in the presence of benzoate has now been identified as described by Trudgill (1969). The aqueous-ethanol soluble material from a reaction system incubated for $1 \mathrm{~h}$ with benzoate as substrate contained a compound which co-chromatographed with authentic benzoyl hydroxamate in the two TLC solvents used. Both compounds gave a purple-brown colour when the plates were sprayed with ethanolic ferric chloride. This compound was absent from reaction mixtures which were stopped at zero time or from which the benzoate was omitted.

The authors would like to thank Emeritus Professor W. C. Evans for synthesis of intermediates and for inspiration, and Dr P. W. Trudgill for practical help with synthesis of CoA esters and valuable discussion. The project received financial support from the SERC.

\section{REFERENCES}

Aftring, R. P. \& TAYlor, B. F. (1981). Aerobic and anaerobic catabolism of phthalic acid by a nitraterespiring bacterium. Archives of Microbiology 130, 101-104.

Balba, M. T. \& Evans, W. C. (1977). The methanogenic fermentation of aromatic substances. Biochemical Society Transactions 5, 302-304.

Balba, M. T. \& Evans, W. C. (1980). The anaerobic dissimilation of benzoate by Pseudomonas aeruginosa coupled with Desulfovibrio vulgaris, with sulphate as terminal electron acceptor. Biochemical Society Transactions 8, 624-625.

Bauchop, T. \& ElsDen, S. R. (1960). The growth of micro-organisms in relation to their energy supply. Journal of General Microbiology 23, 457-469.

BLAKLEY, E. R. (1978). The microbial degradation of cyclohexanecarboxylic acid by a $\beta$-oxidation pathway with simultaneous induction to the utilization of benzoate. Canadian Journal of Microbiology 24, 847855 . 
Clinkenbeard, K. D., Sugiyama, T., Moss, J., Reed, W. D. \& LANE, M. D. (1973). Molecular and catalytic properties of a cytosolic acetoacetyl coenzyme A thiolase from avian liver. Journal of Biological Chemistry 248, 2275-2284.

DAGLEY, S. (1975). A biochemical approach to some problems of environmental pollution. Essays in Biochemistry 11, 81-138.

DieckmanN, W. (1894). Reduction des $\beta$-ketohexamethylencarbonsaüreesters zur hexahydrosalicylsaüre. Berichte der Deutschen Chemischen Gesellschaft 27, 2475-2477.

Dutton, P. L. \& Evans, W. C. (1968). The photometabolism of benzoic acid by Rhodopseudomonas palustris: a new pathway of aromatic ring metabolism. Biochemical Journal 109, 5-6P.

Dutton, P. L. \& Evans, W. C. (1969). The metabolism of aromatic compounds by Rhodopseudomonas palustris. Biochemical Journal 113, 525-536.

DutTon, P. L. \& Evans, W. C. (1976). The metabolism of aromatic compounds by Rhodospirillaceae. In The Photosynthetic Bacteria, pp. 719-726. Edited by R. K. Clayton and W. R. Sistrom. New York: Plenum.

Guyer, M. \& Hegeman, G. (1969). Evidence for a reductive pathway for the anaerobic metabolism of benzoate. Journal of Bacteriology 99, 906-907.

Krueger, R. C. (1952). Crystalline acetoacetic acid. Journal of the American Chemical Society 74, 5536.

LAPIDOT, Y., RAPPOPORT, S. \& WOLMAN, Y. (1967). Use of esters of $N$-hydroxysuccinimide in the synthesis of $N$-acylamino acids. Journal of Lipid Research 8, 142-145.

O'Brien, W. J. \& Frerman, F. E. (1977). Evidence for a complex of three $\beta$-oxidation enzymes in Escherichia coli: induction and localization. Journal of Bacteriology 132, 532-540.

ORMEROD, J. G. (1956). The use of radioactive carbon dioxide in the measurement of carbon dioxide fixation in Rhodospirillum rubrum. Biochemical Journal 64, 373-380.

Ougham, H. J. \& Trudgill, P. W. (1982). Metabolism of cyclohexaneacetic acid and cyclohexanebutyric acid by Arthrobacter sp. strain CA1. Journal of Bacteriology 150, 1172-1182.

Overath, P., Pauli, G. \& Schairer, H. U. (1969). Fatty acid degradation in Escherichia coli. An inducible acyl-CoA synthetase, the mapping of oldmutations and the isolation of regulatory mutants. European Journal of Biochemistry 7, 559-574.

Rho, E. M. \& Evans, W. C. (1975). The aerobic metabolism of cyclohexanecarboxylic acid by Acinetobacter anitratum. Biochemical Journal 148, 11-15.

TAYlOR, B. F., CAMPBell, W. L. \& ChINOY, I. (1970). Anaerobic degradation of the benzene nucleus by a facultatively anaerobic microorganism. Journal of Bacteriology 102, 430-437.

TAYLOR, D. G. \& TRUDGILL, P. W. (1978). Metabolism of cyclohexanecarboxylic acid by Alcaligenes strain W1. Journal of Bacteriology 134, 401-411.

Trudgill, P. W. (1969). The metabolism of 2-furoic acid by Pseudomonas F2. Biochemical Journal 113, 577-587.

Weeks, G., Shapiro, M., Burns, R. O. \& Wakil, S. (1969). Control of fatty acid metabolism. 1. Induction of the enzymes of fatty acid oxidation in Escherichia coli. Journal of Bacteriology 97, 827-836.

Whittle, P. J., Lunt, D. O. \& Evans, W. C. (1976). Anaerobic photometabolism of aromatic compounds by Rhodopseudomonas $\mathrm{sp}$. Biochemical Society Transactions 4, 490-491.

Williams, R. J. \& Evans, W. C. (1975). The metabolism of benzoate by Moraxella species through anaerobic nitrate respiration : evidence for a reductive pathway. Biochemical Journal 148, 1-10. 